\title{
Faculty Perceptions of Chinese Graduate Students' Communication Challenges in the Science and Engineering Disciplines
}

\author{
Jim Hu (Thompson Rivers University)
}

\begin{abstract}
This paper reports the findings of in-depth interviews with six science and engineering faculty members at a major Canadian university regarding their experiences with and perceptions of Mainland Chinese ESL graduate students' challenges in using English in the disciplines. Results suggest great cultural and linguistic challenges of the students; however, helpful guidance and interactive feedback-based conferencing could lead to student progress. Nevertheless, the faculty longed for English and technical writing courses for ESL graduate students. The faculty did not perceive plagiarism to be a major issue among Chinese ESL graduate students and adopted an educational approach toward sporadic inappropriate textual borrowing.

Abstract

Cet article expose les résultats obtenus lors d'entrevues avec six professeurs de science et d'ingénierie dans une université canadienne. Les entrevues se centraient sur leurs expériences et leurs perceptions sur les étudiants chinois de troisième cycle et les défis que ces derniers rencontraient en utilisant l'anglais dans les différentes disciplines. Les résultats montrent en effet de gros défis linguistiques et culturels à surmonter mais qu'un service de conseils et d'aide interactive pourrait aider les étudiants à progresser. Le département a néanmoins choisi des cours d'écriture technique en anglais pour les étudiants de troisième cycle. Cependant, les professeurs ne perçoivent pas que le plagiat est un problème majeur chez les étudiants chinois en cours d'anglais et ont de ce fait adopté une approche éducative envers des emprunts textuels sporadiques inappropriés.
\end{abstract}

\section{INTRODUCTION}

Considerable research has been conducted to study English-as-a-second-language (ESL) graduate students' writing in humanities and social sciences (HSS) in North America (e.g., Cadman, 1997; Casanave, 1995; Connor \& Kramer, 1995; Connor \& Mayberry, 1996; Fox, 1994; Leki, 1995; Prior, 1991, 1995; Silva, 1992); HSS writing is considered highly complex and culturally challenging (Cadman, 1997; Casanave \& Hubbard, 1992). However, much less attention has been paid to how ESL graduate students in sciences and engineering (SE) undertake writing in their disciplines, which theoretically have unique processes and challenges (Braine, 1989, 1995; Casanave \& Hubbard, 1992). It is in SE disciplines that most Mainland Chinese graduate students study. To contribute to this body of research, I conducted a doctoral dissertation study at the University of British Columbia (UBC) during 1997-2000 ( $\mathrm{Hu}, 2000)$, exploring the academic writing processes and challenges of 15 Chinese ESL graduate students in SE disciplines through multi-case in-depth interviews with the students. In order to obtain an alternative 
perspective on the challenges, I interviewed six SE faculty members who had supervised or co-supervised Chinese graduate students including those who participated in my dissertation study. This paper briefly introduces the dissertation study but focuses mainly on the interviews with the faculty to learn about their experiences with and perceptions of the cultural and linguistic challenges of Chinese ESL graduate students studying in SE programs at UBC.

\section{Phases of the Study}

The study evolved in four phases. In Phase I, I inquired about and found little formal ESL support services at UBC and decided to study the challenges of Chinese ESL graduate students of Wood Science at UBC who wrote course assignments and research proposals. In Phase II, I conducted a pilot study of two Chinese doctoral students from Wood Science using semi-structured interviews. In Phase III, I conducted interviews with each of 13 other Chinese graduate students in various SE disciplines (see $\mathrm{Hu}, 2009$, for a discussion of the emerging study design). In Phase IV, I had one in-depth interview with each of six SE faculty members. This paper focuses primarily on the last phase.

\section{LITERATURE REVIEW}

With an increasing number of Mainland Chinese graduate students studying at North American and other English-speaking institutions, much research has been conducted to study the academic experiences of these students. Most of these studies were based on data collected through semi-structured interviews with individual students in HSS and SE disciplines (e.g., Hu, 2000, 2005; Huang \& Klinger, 2006; Qian \& Krugly-Smolska, 2008; Windel et al., 2008). Some were based on surveys of professors who had taught ESL international graduate students including Chinese students (e.g., Casanave \& Hubbard, 1992; Cooley \& Lewkowicz, 1997) or interviews that included both professors and Chinese graduate students (Bitchener \& Basturkmen, 2006). The major findings of this line of research are in three areas.

First, all the studies found that Mainland Chinese graduate students have considerable language difficulties in activities such as oral presentations (e.g., Casanave \& Hubbard, 1992; Hu, 2000; Windle et al. 2008); class discussions (Windle et al., 2008); and local or sentence-level difficulties in grammar, vocabulary, and usage in writing (e.g., Bitchener \& Basturkmen, 2006; Casanave \& Hubbard, 1992; Hu, 2000, 2005; Qian \& Krugly-Smolska, 2008). Furthermore, the students have difficulties with clear expression of meaning, logical development of ideas, coherence at the inter-sentential and paragraph levels, and appropriate academic style including register, format, and citation in writing 
(Bitchener \& Basturkmen, 2006; Casanave \& Hubbard, 1992; Hu, 2000, 2005). The linguistic challenges are particularly prominent during the first one or two semesters of studies. Second, parallel to and interwoven with linguistic difficulties are the students' cultural challenges in meeting the expectations of the host academic community (e.g., Bitchener \& Basturkmen, 2006; Cadman, 1997; Fox, 1994; Hu, 2000; Huang \& Klinger, 2006; Windle et al., 2008) as the students were used to spoon-fed lectures in class and independent study after class, all in preparation for exams in China. Confucian-oriented teaching encourages obedience, and respect for the teacher and authority including published writing, but not critical thinking (Huang \& Klinger, 2006), whereas Socratic-oriented North American education (Huang \& Klinger, 2006) encourages questioning, debates, and critical and original thinking. Given the disparity between the academic background in China and the academic expectations at the host institution, Chinese graduate students are bound to encounter huge cultural challenges and shocks. Third, to overcome the difficulties and challenges, Chinese graduate students have developed coping strategies that are mostly successful, such as relying on a strong work ethic (Huang \& Klinger, 2006), reading model journal articles and imitating the writing style, resorting to knowledge in their first language and translation, and turning to supervisors for advice and feedback (e.g., Hu, 2000, 2003; Qian \& Krugly-Smolska, 2008).

However, as most of the research focuses on the perceptions of Chinese graduate students (except, for example, Bitchener \& Basturkmen, 2006), Huang \& Klinger (2006) called for comparisons with the views and experiences of faculty members who have taught or supervised Chinese graduate students. This paper complements the current research and supplies the other side for comparison through in-depth interviews with individual faculty members.

\section{RESEARCH QUESTION}

The purpose of the doctoral study was to explore the academic writing processes and challenges of Mainland Chinese graduate students in sciences and engineering at UBC, specifically, how the students tried to complete the written course assignments and research proposals required by their programs. Phase IV of the study sought to obtain faculty perceptions of the academic experiences of Chinese graduate students. Thus the research question for this phase was: How do the faculty perceive the academic experiences of Mainland Chinese graduate students? 


\section{METHODOLOGY}

In order to seek an in-depth understanding of faculty perceptions of Chinese graduate students writing in the disciplines, this study phase followed a qualitative design and collected data using semi-structured qualitative interviews. In $\mathrm{Hu}$ (2009), I provided a detailed argument for adopting the qualitative design for the study.

\section{Faculty Participants}

In February 1998, I invited, by mail followed by email, 17 faculty members who were the co/supervisors and/or course instructors of the student participants. However, only seven responded positively. Although one of them accepted the interview, he appeared to be too busy to provide meaningful responses. Therefore, I had to abandon the data collected in that interview. Table 1 below summarizes the background information about the six participants (Note 1). Two participants were from Wood Science, one from Food Science, and three from Electrical Engineering (EE). All had had considerable experience teaching and supervising Chinese ESL graduate students. In addition, they had all taught graduate and undergraduate courses with Chinese students, including some from Hong Kong and Taiwan. Their rich experience with Chinese students added to the validity of the data.

Table 5.1: Faculty Participants

\begin{tabular}{|l|l|l|l|l|l||}
\hline \hline NAME & GENDER & DEPT & POSITION & $\begin{array}{l}\text { YEARS AS FULL TIME AT } \\
\text { UBC + AS ADJUNCT AT UBC } \\
\text { OR FULL TIME ESLEWHERE }\end{array}$ & $\begin{array}{l}\text { CHINESE GRADS } \\
\text { SUPERVISED } \\
\text { THEN+BEFORE }\end{array}$ \\
\hline Ellis & $\mathrm{M}$ & Wood Sci & Prof & $10+7$ & $3+3$ \\
\hline Irvin & $\mathrm{M}$ & Wood Sci & Prof & 14 & $3+12$ \\
\hline Oates & $\mathrm{M}$ & Food Sci & Assoc. Prof & 15 & $5+6$ \\
\hline Ray & $\mathrm{M}$ & EE & Assoc. Prof & $4+3$ & $2+6$ \\
\hline Smith & $\mathrm{M}$ & EE & Prof & $15+2$ & $3+11$ \\
\hline Adams & $\mathrm{M}$ & EE & Prof & 32 & $4+14$ \\
\hline \hline
\end{tabular}

\section{Data Collection Technique}

I interviewed each of the six faculty members individually for 60-90 minutes at a time and location convenient to both them and me. I used semi-structured interviews with a guide to help me maintain focus and yet allow exploration. Prior to each interview, I tried to access as much information as possible about the faculty member, the program with which he was associated, and relevant courses through the Internet and course outlines provided by the students. Thus I hoped to ask informed questions. All the interviews were audio-taped with the participants' permission and transcribed. 


\section{Data Analysis}

I adopted an interpretive, inductive approach in my data treatment ( $\mathrm{Hu}, 2009)$; that is, I read and reread the transcripts and other documents to search for recurrent themes. Specifically, I coded meaningful transcript segments on paper, wrote the codes on one separate sheet of paper, searched for interrelationships between codes, and thus for themes and subthemes. Out of the individual interview files and documents, I built several theme-based files which allowed easy access to all the segments under one code. The research question I asked for this study phase and the interview guides influenced my analysis.

\section{RESULTS AND DISCUSSION PROGRAM REQUIREMENTS \\ TOEFL and Prior Degrees}

For all the SE graduate programs involved in the study, the Test of English as a Foreign Language (TOEFL) in paper-based format (PBT) was the only English language requirement for admission with a minimum score of 550 except in Electrical Engineering, where the minimum was 600. All the student participants scored well above the minimum for their programs. However, according to the faculty, TOEFL PBT with an emphasis on grammar and vocabulary knowledge did not reflect the English skills required for academic studies, especially academic writing and listening. The former is needed to write academic papers; the latter is vital for understanding lectures and interacting with peers and professors. These two areas plus technical terminology constituted three major areas of linguistic weakness of new Chinese graduate students.

The new generation Internet-based TOEFL, or TOEFL iBT, claims to reflect language used in real academic settings (Gallagher, 2006). However, research is necessary to find out if ESL students meeting the minimum TOEFL score requirements indeed have adequate English skills for academic success in a specific graduate or undergraduate program.

The prior degree required for a UBC Master's program was generally a relevant Bachelor's, but all the Chinese student participants except one held a Master's from China. In Electrical Engineering, a prior Master's was a requirement for students from China "because we found that a person from China with a Bachelor's degree was not equivalent to people coming from North America. So we insist on that" (Ray) (Note 2). Although doctoral programs generally required a prior Master's degree, two doctoral student participants already had a $\mathrm{PhD}$ in a related area from China. In sum, as far as TOEFL and prior degrees are concerned, the Chinese student participants well exceeded the requirements. 
Coursework, Comprehensive Exams, Research Proposals, and Theses/Dissertations

UBC Master's students generally needed to take courses and then write either a thesis or a project. Many courses required written language-intensive project reports or papers and sometimes, oral presentations. The thesis, but not the project, generally required a department-level defense. Apart from courses, doctoral students needed to take a comprehensive or qualifying exam (or comps), complete a research proposal, and write and defend a dissertation. In Wood Science, for example, doctoral students were expected to finish coursework, comps, and the proposal in the first two years. For Chinese ESL students new to the academic culture and weak in English skills, such an expectation presented a huge challenge. However, Ellis of Wood Science did not consider it unreasonable, arguing "It is a $\mathrm{PhD}$ achievement. It's not easy but it shouldn't be."

\section{CULTURAL PROBLEMS OF CHINESE GRADUATE STUDENTS}

As in other studies (e.g., Bitchener \& Basturkmen, 2006; Cadman, 1997; Fox, 1994; Huang \& Klinger, 2006; Qian \& Krugly-Smolska, 2008; Windle et al., 2008), the faculty participants in this study noted various cultural issues in their interaction with Chinese graduate students. The issues include a reluctance to say "no," shyness, and lack of critical thinking.

\section{Not Saying "No"}

The faculty observed that Chinese graduate students were willing to work hard in academic and linguistic development. The students tended to be well prepared academically and have good basic math and science background. However, all the faculty were puzzled by Chinese students not saying "no," for instance, when they did not understand a professor. The following interview excerpt from Ellis illustrates the concern.

Another issue, and this is probably cultural, Chinese students never say "no." You ask them "Have you taken this, covered this material before?" "Oh, yes." "Have you learned this before?" "Yes." "Can you do this?" "Yes." They never say "no" or at least when they first come. They are reluctant to admit maybe they don't understand something. You know in our culture here we are very aggressive about this. We want to know exactly what you know, what you don't know. If you don't know, that's fine; we'll help you learn. Right? So, that's maybe a cultural issue. So you ask Chinese students "Have you had a seminar before?" "Oh, yes, I had a seminar." "We'll put you in a seminar course." Then you put them in a 
seminar course. The first time they have to stand up and give a seminar [presentation], it's a real difficult situation, difficult experience for them. And you know, you don't want to make a difficult experience for people.

It is true that Chinese students new to North American culture in general do not like to say "no" as doing so reveals ignorance, especially for those who have been top students in their Chinese classes. It is often considered a shame to admit ignorance. This is in contrast to North American culture, where admitting ignorance is often viewed positively since doing so indicates one's honesty and possibly a desire to learn.

As Ellis mentioned, the issue about seminars could be due to cultural differences, at least partly. It might be true that a student had taken a graduate seminar in China, but the seminar was different. Even now, it is likely that the seminar professor will talk all the time as in other Chinese classes. Students seldom take the floor but typically, sit listening in attentive silence (Liu, 2002; Windle et al., 2008), and stand when asking a question. But in Canada, students can ask a question or even challenge the teacher in the midst of the latter's talk. Some graduate seminars, like the one in Wood Science, focused on students' research proposals to be presented to class orally as well as to the instructor in writing.

The best strategy for students to deal with the problem, according to Irwin of Wood Science, is being frank about what one knows and what one does not know. He advised:

The way we look at it, when somebody says "Do you understand?" "It's better to say "Well, I understand part of it, not this," and be frank about that...doesn't lead to when somebody says to you "Do you understand this?" You say "Yes." Then when you ask them a question, they don't know the answer...Then you ask another question; they dig themselves into a big hole.

Frankness and open dialogues are a key to avoiding or overcoming such cultural problems; nevertheless, there are genuine linguistic issues involved in oral communication as discussed later.

Being Shy

Another closely related problem of Chinese graduate students was shyness in expressing views and asking questions. Again, this was a common concern for all the faculty. For example, Adams of Electrical Engineering noted: 
Chinese students tend to be less willing to express concerns, to be outgoing and aggressively seek out things they don't understand. I think sometimes students will not let you know that they don't understand something when they should. So they tend to be perhaps more respectful to faculty members than faculty members are used to. Sometimes it depends on the students to let you know things. Perhaps they are shy to do.

Smith of Electrical Engineering expressed his frustration similarly: "They often remain silent even though they don't understand when they are asked if they understand some questions. This leaves the instructor frustrated." Chinese students' shyness can be traced to "culturally influenced moral imperatives" (Windle et al. 2008, p. 80). In China, at least in the past 40 years, there has been a movement in schools at all levels promoting, with students competing for, the title of a so-called "three-good student." Criteria for the title include being obedient (namely, not challenging the teacher or text seen as authority), being modest (synonymous to shy), and getting high academic grades (Windle et al, 2008). This movement stems from the Confucian ideology, which values obedience, politeness, and modesty. As revealed by Huang and Klinger (2006), Chinese students usually consider it an embarrassment or shame to admit not understanding the teacher in class although they might ask the teacher after class or seek help from classmates after or in class. I am myself puzzled sometimes as this happens to my Chinese ESL university students. Furthermore, in contrast to self-centered North American students, Chinese students care about what the teacher and/or other students think about them and consider it a "loss of face" when not being able to answer or respond to the teacher's questions correctly (Huang \& Klinger, 2006). In this sense, it is better to remain silent than venture to make mistakes in public. Evidently, the tendency to not say "no" or be shy is deeply rooted in the native culture, and therefore, very difficult, if not impossible, to change in a short time. Teachers will need to deliberately check students who are shy to ask questions or respond to questions openly. If possible, group activities may offer less threatening opportunities for such students to express opinions.

\section{Lacking Critical Thinking in Graduate Writing}

Chinese students were considered more introverted, more polite, and better at implementing instructions, but less critical, innovative, confident, and aggressive than non-Asian international students such as Africans and Europeans (Ray and Oates). As mentioned above, historically, the Chinese education system based on Confucian philosophy encourages obedience and respect for teachers, who are 
regarded as symbols of knowledge and authorities over students (Huang \& Klinger, 2006). It often ridicules or shames questioning and authority-resisting behaviors, and regards students exhibiting such behaviors in class as trouble-makers. Similarly, published text is regarded as a symbol of knowledge and authority as well. In this connection is another element of Confucian philosophy, namely, harmony as I found when interviewing a student participant about what he thought was most challenging in research writing. The student found discussion challenging because discussing his new ideas was difficult. He had to argue for his new methods and findings against competing alternatives. Such an argument not only was difficult in terms of accurate and forceful expressions but also caused him to feel somewhat uncomfortable as he had been used to "exchanging ideas" with colleagues in China instead of arguing.

Maintaining harmony is a value even in research writing in China (cf. Ballard \& Clanchy, 1991; Cadman, 1997; Shen, 1989). If two researchers have different views or findings on a common topic, they may exchange ideas. But if one researcher chooses to attack or argue with another who has a different view, that could cause the latter a "loss of face," which in turn could create an enemy. The student participant just mentioned also suggested that Chinese scholars do not like to openly criticize others, especially authorities. If they have new ideas or findings, they usually claim them as such without having to reject particular opponents in order not to start a war. At best they may refer to the field in general. Thus, Chinese scholarly tradition favors a conserving attitude to knowledge over controversy and values appreciation over criticism, and in this tradition there is willingness, and often a pressing force, to respect authority and tolerate ambiguity, especially opponents who are one's academic superiors (Ballard \& Clanchy, 1991). Against this background, it is not surprising that Chinese students were perceived to behave obediently, submissively, and respectfully. For example, Oates of Food Science observed:

I think they are very good at reproducing something, but going beyond that into new ideas and critical thinking is possibly something that is related to culture. They are less likely to be aggressive, and challenge concepts...It's easy to reproduce something that somebody agrees on but if you don't agree with it, then you should go explain why and be forceful and aggressive. That's usually where they have problems.

In fact, Adams and Ray made a distinction in their expectations of undergraduate and graduate students. Undergraduate students were supposed to consume knowledge and the way to find out about their learning was tests and exams. In contrast, graduate students were expected to produce knowledge by 
designing unique or original studies and contributing findings or new knowledge to their fields in project reports.

Even when reading study reports or literature, graduate students were expected to go beyond mere comprehension and "demonstrate their skills and critical thinking, accumulation and summary of studies, put them [in] an organized readable fashion. The vehicle basically is, not the exam, but as a term paper, and possibly as oral presentation" (Oates). In other words, in a term paper, students need to question, analyze, recombine ideas into an argument (Ballard \& Clanchy, 1991), and present what has been accomplished in the literature and what has not been accomplished or accomplished well enough, thus leading to a rationale or directions for further research. This doubtless requires critical thinking skills, and furthermore, competent writing skills.

Associated with the lack of critical thinking, Oates and Irwin pointed out the students' lack of experience in writing term papers. As noted above, the students had generally gone through an exam-oriented education system in China and had had little experience writing English papers. The lack of experience coupled with English language difficulty (see below) presented great challenges to the students. Nevertheless, once the students received guidance and advice, as Irwin and Oates noted, their performance generally improved. Therefore, it is imperative that professors provide clear, explicit assignment instructions and expectations (e.g., marking criteria) that are comprehensible to ESL students. Additionally, offering models also helps inexperienced students.

\section{LINGUISTIC CHALLENGES OF CHINESE GRADUATE STUDENTS}

According to Ellis, Chinese graduate students had more difficulty with English than those from European countries because Romance languages such as French, Spanish, German, and English are genetically inter-related. Chinese is genetically unrelated to and distant from English; thus, the students have less language transfer from their first language (L1) and more problems understanding the subtleties of English and constructing sentences correctly, idiomatically, and coherently. Ray also noted more linguistic and cultural difficulties Chinese graduate students had than European and African ESL students. These observations confirm the findings of linguistic difficulties of Asian ESL students reported in Casanave \& Hubbard (1992), Cooley \& Lewkowicz (1997), and Crowe \& Peterson (1995). The linguistic

distance between Chinese and English, cultural distance between the students and North American academia, difference between the exam-oriented English learned in China and the communicative English needed in Canada (Hu, 1993; White, 1998), and finally the lack of experience using English for academic purposes contributed 
to the linguistic challenges of Chinese graduate students such as speaking, technical vocabulary, and academic writing especially when they first arrived.

\section{Speaking and Vocabulary}

Some faculty participants perceived speaking to be a major problem for Chinese graduate students, especially in the beginning of their studies. For example, in a gradate seminar in Wood Science usually taken during the first year of a student's program, students needed to present research proposals to the class. This task proved daunting for Chinese students who had rarely given an oral English presentation before coming to Canada. Irwin commented on the challenge:

They haven't had much experience doing that [giving presentations] in

English and they don't have experience producing good overheads. They make their presentation, then there're questions, and they have difficulty understanding what question is being asked, and then there's difficulty having an answer for it. I guess there is a whole set of other issues around doing presentations and interacting with English-speaking people.

This is not surprising given that students in China seldom take the floor as mentioned earlier, let alone giving English presentations. In fact, oral presentations and related linguistic skills such as listening, pronunciation, inclass discussions, group work (with English-speaking peers), and communicating with local people, are so difficult for Chinese students to master, especially during the first year of study that Windle et al. (2008) in their study of eight Chinese ESL graduate students at another Canadian university consider them to be "impermeable aspects" (p. 80) of the target culture.

Another problem of the Chinese graduate students was limited vocabulary, both general and discipline-specific, especially in the beginning. Classes in sciences and engineering at Chinese universities are generally offered in Chinese. Although discipline-specific resources were available at most Chinese universities when the data were collected, they were rather limited. Thus, the students had very limited exposure to English in their disciplines in China. They might have the knowledge in Chinese but not English. As Ellis observed, "Often I have heard students complain that they know the concepts in Chinese but just don't know the English.... Often they can't match the English words with their concepts in Chinese." Sciences, for instance, biology and chemistry, are notorious for technical terminology which often includes lengthy multi-syllabic words that are likely even more difficult to understand orally than in writing. The general vocabulary of most of the students was also limited (see also Qian \& Krugly-Smolska, 2008). As my student participants in Food and Wood Sciences complained, vocabulary presented a huge challenge to their studies at the 
start $(\mathrm{Hu}, 2000,2005)$. The difficulty with vocabulary doubtless adds to challenges in academic listening and speaking.

Academic Writing

While ESL graduate students are "inducted" into particular disciplines through lectures, discussions, readings, presentations, and laboratory work, it is through written assignments that the success of their academic performance is most commonly judged (Ballard, 1984; Casanave \& Hubbard, 1992; Leki \& Carson, 1994; Norton \& Starfield, 1997). The writing challenges of Chinese graduate students included grammar, style, organization, format, and source borrowing.

\section{Grammar, style, and organization}

The faculty noted various academic or research writing problems of Chinese graduate students including spelling, grammar, clarity, style, and paper organization as reported in other studies (Bitchener \& Basturkmen, 2006; Casanave \& Hubbard, 1992; Huang \& Klinger, 2006; Qian \& Krugly-Smolska, 2008; Windle et al., 2008). Despite the availability of the computer spell checker, some students forgot either to run the checker or to check manually after applying the checker. It is well known that as long as a word is in the dictionary, the checker may not highlight the spelling error. Ray was especially irritated by these errors. The two most common areas of grammar problems were verb tenses (e.g., mixing up the present and past) and articles. Adams expressed his frustration this way: "... the definite article, the indefinite article. It's chaotic with most students who are fresh. I mean, they are in places where they shouldn't be and then they are not in places they should be." Smith pointed out that "often there are sentences without a single article." These two areas, verb tenses and articles, in particular exemplify a lack of L1 to L2 (second language) transfer as Chinese, being an analytical language, relies on words but not verb inflections to reflect times and it uses no articles. Naturally, it takes much longer for Chinese students to grasp and use the features correctly.

Aside from grammar, issues such as clarity, style and organization also present challenges to Chinese students (see especially Bitchener \& Basturkmen, 2006; Casanave \& Hubbard, 1992). Casanave \& Hubbard (1992) distinguish grammar and spelling errors as local errors vis-à-vis clarity (content), style, and organization which are global issues as the latter tend to concern a paragraph or the paper as a whole rather than a single sentence. As my interviews with the faculty revealed, many Chinese graduate students had difficulties on both local and global levels. For instance, Smith noted, "written and oral communication is a big problem with many Chinese students. I have [some] students write up to 8 or 9 drafts. Their writing just doesn't make sense to me." In my study, as in Casanave and Hubbard (1992), most faculty participants complained about Chinese 
students' local errors (see above) but ironically, regarded global issues as much more important and usually based their assessment more on global than local qualities possibly because global issues have a greater impact on the comprehension of a paper.

\section{Format}

There was no specific writing style, such as American Psychological Association (APA) format, prescribed for academic writing in the SE programs. Writers were supposed to follow the leading journals in their disciplines or specific areas, just as Casanave and Hubbard (1992) found in their survey study. Although graduate programs generally had guidelines for Master's theses and doctoral dissertations, Irwin mentioned "for other reports generally we don't have a specific format. So the students select a format that is appropriate for the type of document they are writing." However, my interviews with the students found that the lack of specific format instructions left many students groping in the dark. Students in the Huang and Klinger (2006) study too found the academic writing process challenging in terms of format and expectations. What made the matter worse was that different journals might follow different formats, which means that different courses might require different formats, even in the same department. For example, "Journal of Food Science has appropriate citations that are different from, say, Journal of Nutrition or Biological Chemistry or something like that. They are all unique" (Oates). Given the lack of explicit formats to follow, it was not surprising that students were often confused or lost regarding citations even after one to two years in their program.

However, not all the professors considered format important but preferred to focus on the content. Adams, for instance, stated "I'm not worried about the format...Clarity conveyed to me of what they are doing matters a lot more than that. As long as I understand they know what they are doing, that's what I ask for." Apparently, at least in the engineering programs, style format was not a major concern for course assignments, although the same is not true for theses and dissertations (see below).

Plagiarism

Plagiarism is a very illusive term, the interpretation of which may vary from university to university (Note 3 ) and from professor to professor. For example, UBC posts a rather broad explanation: Plagiarism "includes but is not limited to the presentation or submission of the work of another person, without citation or credits, as the student's own work...zero credit or some other mark may be assigned by the faculty for the plagiarized submission" ("UBC Regulation on Plagiarism"). It is up to the reader to interpret what constitutes work and how much work amounts to work punishable by the policy. Also, the penalty appears 
to be limited to the submission under question. The consequence appears less severe compared with that at some other North American universities. There has been considerable discussion of the highly controversial issue of plagiarism in recent research literature from cultural, philosophical, historical, legal, textual, and pedagogical perspectives with a wide range of interpretations (e.g., Abasi \& Graves, 2008; Currie, 1998; Howard, 1999; Hu, 2001; Myers, 1998; Pennycook, 1996; Picorari, 2003; Shi, 2006).

The perceptions on plagiarism of the faculty seem to reflect the UBC explanation. As my interviews revealed, plagiarism on a small scale (for example, copying one or two sentences from a source without referencing) existed sporadically among Chinese graduate students but did not seem to be a major concern to the faculty. Ellis of Wood Science pointed out that plagiarism was a cultural concept, being viewed differently in different cultures. Irwin also of Wood Science elaborated:

I haven't encountered that as a problem. Once or twice we had a student having taken more material essentially from a book to respond to a particular problem. I have the impression that it wasn't plagiarism, but rather they thought this was a suitable way to respond to the problem of the past... is to go and find the book that discusses this and submit that...Then we told them that wasn't acceptable; then they understood that.

Oates followed a similar approach, namely, explaining the issue and raising students' awareness, as revealed in the interview.

O: If the thought or concept is the same but expressed differently, I don't worry about it. If the wordage is common and I've seen it before, then I do worry about it. I bring to their attention. I don't fail anybody on plagiarism, but I let them know. Plagiarism sometimes is very easy to do subconsciously. But when you purposely copy a sentence identical, it's a serious thing. If you are aware how serious it is, you probably won't do it again.

J: I see. Would you turn the paper back to the student and tell him/her to rewrite these parts?

O: No, no. I'd bring it to their attention. Maybe marked down for it, but I wouldn't unless the whole paper was one big plagiarism, of course. But if it is a few things here and there, it's a matter of them being aware of that.

From my interviews with the above three faculty participants, it appears that they tolerated paraphrasing (i.e., presenting others' ideas in one's own words) 
without citing the source and only deemed unacceptable what might be called literal reproduction or verbatim copying. Most researchers, educators, and institutions in English-speaking countries now consider paraphrasing without providing the source a form of plagiarism (e.g., Leki, 1998; Stern, 2006).

Adams, too, did not think plagiarism happened frequently, but he was concerned about students' presenting a peer's work as one's own, which is cheating, a different form of plagiarism than inappropriate citation.

I don't mean plagiarism happens frequently, but the concern is. And there are a lot of reasons that give concern to that. Sometimes in a research group people work on similar problems as well as descriptive material, and if the student has difficulty with English, there is a big temptation for them to take descriptive language from another thesis to put in their own. You can't do it. It's not right. Students have to be alert not to do that. (Adams)

Ray did not encounter plagiarism among his graduate students. To him, graduate students, whom he also called research students, were supposed to conduct unique research projects.

I think in postgraduate there is less concern than undergraduate, the reason being postgraduates are by definition doing more individual work. And most students have fairly unique projects to do. So there's no opportunity for much plagiarism, while in undergraduate they have to do the same thing, so there's a lot of opportunity. So to answer your question, I haven't noticed among my students particularly. (Ray)

Ray had an important point as he thought graduate students were supposed to conduct and report original research. Such research, by definition, cannot be found elsewhere. However, the statement does not account for writing which is required to argue for new research, namely, literature reviews that must discuss past research.

To sum, the faculty did not perceive plagiarism to be a major problem among Chinese graduate students. Plagiarism to them meant verbatim copying of considerable text from a source without acknowledgement or presenting a peer's work as one's one own. As the students were from China with little experience writing English papers and had had no benefit of English courses at UBC, the faculty generally took an educational approach to unintentional plagiarism through explanation and awareness-raising in feedback. This approach is consistent with the literacy practice recently reported in another Canadian study involving 15 professors and four graduate international students in two academic programs: Communication and Education (Abasi \& Graves, 2008). The professors felt it their responsibility to 
assist and socialize their graduate students in "becoming full participants in the academy and proficient in the academic literacy practices" (Abasi \& Graves, 2008, p. 224). Although there were "transgressive textual borrowings" (p. 226), the professors did not see any "evidence of intention to deceive" (p. 226) but regarded the students' inappropriate citation as a learning issue and therefore, did not accuse the students of plagiarism. As pointed out earlier, there are clearly different interpretations of plagiarism among faculty in North American universities and different approaches to deal with the issue. It may be fair to suggest considering various factors in particular cases in dealing with perceived plagiarism involving ESL students.

\section{SUGGESTIONS FOR HELPING ESL STUDENTS WITH ENGLISH}

When asked about how Chinese graduate students could prepare English prior to enrollment at UBC, the faculty participants offered various suggestions. For example, Ellis emphasized listening-speaking skills as he noticed poor oral skills of his students. To justify listening, he reasoned that "if they could listen to lectures better, they can hear the words and understand the words better; then at least they can go into a class fairly quickly and start learning, whereas if their listening skills are poor, they will [need to] improve them as well as the writing skills." With increasingly easy access to the radio and the Internet, namely, both English learning resources stored at websites and live TV or archived TV videos through the Internet, listening sources should not be a problem for many university students or graduates in China now. For example, the website http://erivas.disted.camosun.bc.ca/Learning\%20Resources/Listening_Links.html contains links to these and other sources. It may even be easier for graduates to find time to listen to English in China since once they start studies in North America, they may not have much time for such practice as they struggle with academic courses as well as living in a foreign country.

Ray cited two parts of English that students could improve in China. One was basic English skills including vocabulary, grammar, listening and speaking, reading and writing, and the other was technical writing as the students in his department would need to write papers and reports in technical style. Irwin, too, suggested technical writing as he was aware some universities in China offered a technical English writing course. The course could aid Chinese graduate students immensely in studying in North America or publishing in international journals.

Two faculty participants also made suggestions as to what Chinese graduate students could do after enrollment into academic programs. Smith recommended reading model journal articles to learn about the language, style, organization, conventions as well as ideas of other researchers in the field and thus help improve 
academic writing skills. However, as Barkaoui (2007) suggests, it is better for the instructor to provide what he or she considers as example texts. Ellis, in keeping with Ray on basic skills, recommended improving reading and listening as he elaborated at length.

E: ...take a Time magazine and read, so you got to improve your recognition of words [sight vocabulary], what they mean, with a dictionary. Start reading, so you must practice daily. So I think I try to recommend to students they must read English, not just the textbooks but common English, a newspaper [e.g., Globe and Mail] or a Maclean's [magazine] or something that's interesting and tells them about the environment in the world. That's one thing. The other thing is to watch TV, good quality TV. There are public broadcasting channels that provide good quality[reports], and often with subtitles so that you can have the written words shown as well because...you got to practice visually recognizing words and also how those words sound.

$\mathrm{J}$ : The letter-sound connections.

E: So you decide to watch the PBS [Public Broadcasting Service] channel every week, you are going to watch the news every week, and you are going to read a paper every week. Then if you do this consistently, after 6 months your English fluency will improve because your range of words you've got is improved from 500 to 2000 [for example]. Those are the things students could do to help themselves....

E: The other thing is that within my group you practice. In my lab you practice [speaking] English all the time.

Extensive exposure to English through reading and listening, namely receptive skills, helps students not only expand sight vocabulary but more importantly, develop language sense and move from thinking in L1 to thinking more in L2 along the thinking-language continuum (Hu, 2003), resulting in increased fluency in language processing. The speaking and writing practice, both productive skills, help turn sight or passive vocabulary into active or productive vocabulary.

\section{SUGGESTIONS FOR HOST INSTITUTIONS}

The final part of my interviews with the faculty sought suggestions regarding how host institutions could help Chinese graduate students overcome language difficulties to succeed in academic programs. According to the faculty, one way to deal with the language readiness problem is to offer preparatory courses of language 
and academic culture to students in China before enrollment at the host university or offer such courses to them at the host university before or while they begin graduate studies. In the latter case, the course should be credit bearing; otherwise, the courses may not be attractive or affordable to Chinese graduate students with limited economic means (as credit courses could help win scholarships) or students may not take them seriously. Even though they know language and cultural competence are important for academic success, students are more worried about credit courses which determine their status in academic programs and often, whether they are, or will be, qualified for scholarships. Oates suggested two courses based on what he perceived to be of most need to Chinese graduate students: 1) scientific research writing, and 2) oral presentation skills.

Likewise, Irwin recommended a thesis-writing course:

I: I would like to see a course for graduate students particularly designed around how to prepare a high quality thesis. For the thesis there are two aspects. There is the written English, and then there are all the tables, figures you probably have in the thesis as well... I would really like to see students well prepared in this area so that they can produce high quality documents in word processing.

$\mathrm{J}$ : Part of my recommendations would be a course or program set up to address the needs. I think the needs are there.

Ellis made similar comments on the necessity for UBC to offer formal courses to help ESL graduate students improve language skills. In addition, he suggested admitting new ESL students in May rather than September so that the students could take language courses in the summer to prepare for academic courses in the fall. If ESL students were to take academic courses in September or January right upon arrival, those with weak English skills were bound to experience hardship in meeting course requirements. As Windle et al. (2008) found in their study, English was the most difficult challenge the Chinese graduate students encountered most intensely during their first semester of study in Canada. Being able to take needed language courses before academic courses would certainly alleviate the hardship. A number of universities in Canada such as Thompson Rivers University actually require ESL students, both graduate and undergraduate, to take needed ESL courses before or while studying in academic programs (see www.tru.ca/hse/programs/esl/academic_esal.html).

While all the faculty felt a need for the host university to offer English language courses to help new ESL students upgrade their language skills, Adams did not consider it a core activity of the institution to help ESL students by offering 
credit-bearing language courses. The students should have learned sufficient English prior to admission or should improve English apart from their academic studies. He argued "that's why we have TOEFL and things like that. In principle it's the students' responsibility to be able to do it." But given the fact that many ESL students were not adequately prepared in English, he suggested offering ESL courses as part of continuing education on a cost-recovery basis. Alongside with the language courses, Irwin also desired some informal assessment of ESL students' writing ability in addition to TOEFL when they entered the university. Thus students could receive proper advice regarding what language courses to take to help with academic coursework and thesis/dissertation writing.

\section{CONCLUSIONS AND IMPLICATIONS}

The science and engineering faculty participants in my study perceived great cultural and linguistic challenges of Chinese graduate students in their programs especially in the beginning of the students' studies (see also Bitchener \& Basturkmen, 2006; Casanave \& Hubbard, 1992; Huang \& Klinger, 2006; Qian \& Krugly-Smolska, 2008; Windle et al., 2008). The main reasons include huge differences in culture, language, and educational system. Especially, the students encountered challenges to write papers with correct language, appropriate style and organization, and ideas born out of critical thinking. Nevertheless, with helpful guidance and advice from professors, they were able to make progress. Thus it is important that supervisors and instructors provide clear, comprehensible assignment instructions and marking criteria or expectations. Models are helpful for students lacking experience in writing English papers.

Furthermore, as my interviews with the student participants revealed $(\mathrm{Hu}$, 2000), the students preferred to receive corrective faculty feedback regarding the form and content of their writing as they desired to improve English and academic performances (see also Lee, 2005). Similarly, they desired reinforcing comments. Such positive feedback provided them with needed psychological nourishment, such as encouragement and motivation, for academic growth $(\mathrm{Hu}, 2000)$. On the other hand, if faculty did not provide much feedback on their writing, the students would think that the faculty did not consider language important, and therefore, would not pay close attention to it. Still, depending on the nature of the problem, feedback alone might not be sufficient. Student conferencing after written feedback, namely, interactive feedback-based conferencing, was much more effective than feedback through written comments alone. If time is an issue, providing feedback while conferencing can be an alternative. The students appreciated one-on-one professor-student conferencing for two reasons: the opportunity for the professor to repeat explanations in alternative expressions; and 
building a closer relationship with the faculty, which showed the faculty cared and which could translate into student motivation.

The faculty recommended that new ESL graduate students improve basic language skills such as listening, speaking, reading, and vocabulary as well as writing because all these skills are necessary for academic success in graduate studies. To expand vocabulary and increase reading fluency and listening comprehension, students should read not only academic but also general English texts and watch good TV programs, preferably with subtitles to help connect visual with audio forms. The vocabulary learned will help improve speaking and writing skills. All the faculty desired English and technical writing courses for ESL graduate students although consensus was lacking as to whether the courses should be credit-bearing and whether they should be on a cost-recovery basis. It might be desirable for students to take such courses when available before academic courses. The interviews clearly showed the faculty's longing for badly-needed formal language support for ESL graduate students provided by language professionals rather than by themselves.

The faculty did not perceive plagiarism to be a major issue among Chinese graduate students. Although sporadic inappropriate borrowing of source texts occurred in students' writing, they generally considered it a learning issue for ESL students and took an educational approach through explanation and awarenessraising. This approach seems sensible for ESL students who have not had an opportunity to learn about plagiarism, but for others who have, it could be different. Nevertheless, what remains a challenge for ESL researchers and instructors is to find effective ways to teach ESL students with limited proficiency to write clearly and creatively, not just to quote sources correctly.

\section{POSTSCRIPT}

It is worth noting that since part of my doctoral study was first reported in The Graduate, a UBC newspaper in 1998, new courses have been created at the UBC Writing Centre, targeting academic writing skill development at undergraduate and graduate levels and thesis writing, especially for ESL and science and engineering students. Although the courses are offered on a cost-recovery basis and non-credit bearing, they are available to students who need them. Some of the courses include: Writing for Engineering Students, Getting Ahead with Grammar, Writing with Style, Writing for Graduate Students, and Scientific Writing.

Notes

Note 1. Pseudonyms are used for all the faculty participants in the study.

Note 2. In this paper, to maintain the participants' speech authenticity, no attempt is made to correct language errors or modify the speech unless, otherwise, the meaning becomes unclear.

Note 3. One American university accused another of "plagiarizing" its definition of plagiarism in a university calendar, for the latter apparently did not vary the definition (see Pennycook, 1996).

\section{References}

Abasi, A.R., \& Graves, B. (2008). Academic literacy and plagiarism: Conversation with international graduate students and disciplinary professor. Journal of English for Academic Purposes, 7, 221-233. 
Ballard, B. (1984). Improving students' writing: An integrated approach to cultural adjustment. In

$\mathrm{R}$. Williams, J. Swales, \& J. Kirkman (Eds.), Common ground: Shared interests in ESL and communications studies (pp. 43-52). Oxford, UK: Pergamon Press.

Ballard, B., \& Clanchy, J. (1991). Assessment by misconception: Cultural influences and intellectual traditions. In L. Hamp-Lyons (Ed.), Assessing second language writing in academic contexts (pp. 19-35). Norwood, NJ: Ablex.

Barkaoui, K. (2007). Revision in second language writing: What teachers need to know. TESL Canada Journal, 25(1), 81-92.

Bitchener, J., \& Basturkmen, H. (2006). Perceptions of the difficulties of postgraduate L2 thesis students writing the discussion section. Journal of English for Academic Purposes, 5, 4-18.

Braine, G. (1989). Writing in science and technology: An analysis of assignments from ten undergraduate courses. English for Specific Purposes, 8, 3-15.

Braine, G. (1995). Writing in the natural sciences and engineering. In D. Belcher \& G. Braine (Eds.), Academic writing in a second language: Essays on research and pedagogy (pp. 113-34). Norwood, NJ: Ablex.

Cadman, K. (1997). Thesis writing for international students: A question of identity? English for Specific

Purposes, 16, 3-14.

Casanave, C.P. (1995). Local interactions: Constructing contexts for composing in a graduate sociology program. In D. Belcher \& G. Braine (Eds.), Academic writing in a second language: Essays on research and pedagogy (pp. 83-110). Norwood, NJ: Ablex.

Casanave, C.P., \& Hubbard, P. (1992). The writing assignments and writing problems of doctoral students:

Faculty perceptions, pedagogical issues, and needed research. English for Specific Purposes, 11, 33-49.

Connor, U.M., \& Kramer, M.G. (1995). Writing from sources: Case studies of graduate students in business management. In D. Belcher \& G. Braine (Eds.), Academic writing in a second language: Essays on research and pedagogy (pp. 155-82). Norwood, NJ: Ablex.

Connor, U.M., \& Mayberry, S. (1996). Learning disciplinary-specific academic writing: A case study of a Finnish graduate student in the United States. In E. Ventola \& A. Mauranen (Eds.), Academic writing: Intercultural and textual issues (pp. 231-53). Philadelphia, PA: John Benjamins.

Cooley, L., \& Lewkowicz, J. (1997). Developing awareness of the rhetorical and linguistic conventions of writing a thesis in English: Addressing the needs of ESL/EFL postgraduate students. In A. Duszak (Ed.), Culture and styles of academic discourse (pp. 113-140). Berlin: Mouton de Gruyter.

Crowe, C., \& Peterson, K. (1995). Classroom research: Helping Asian students succeed in writing courses.

Teaching English in Two-Year College, 22(1), 30-37.

Currie, P. (1998). Staying out of trouble: Apparent plagiarism and academic survival. Journal of Second

Language Writing, 7(1), 1-18.

Fox, H. (1994). Listening to the world: Cultural issues in academic writing. Urbana, IL: National Council of

Teachers of English.

Gallagher, N. (2006). Delta's key to the next generation TOEFL test: Six practice tests for the iBT. McHenry, IL: Delta.

Howard, R.M. (1999). The new abolition comes to plagiarism. In L. Buranen and A.M. Roy (Eds.), Perspectives on plagiarism and intellectual property in a postmodern world (pp. 87-95). Albany, NY: State University of New York Press.

Hu, J. (1993). From TESL in Canada to TEFL in China: A focus on methodology. Unpublished Master's thesis, the University of Western Ontario, London, Ontario.

$\mathrm{Hu}$, J. (2000). Academic writing of Chinese graduate students in sciences and engineering: Processes and challenges. Unpublished doctoral dissertation, the University of British Columbia, Vancouver, BC, Canada.

$\mathrm{Hu}$, J. (2001). An alternative perspective of language re-use: Insights from textual and learning theories and L2 academic writing. English Quarterly, 33(1), 52-62.

$\mathrm{Hu}$, J. (2003). Thinking languages in L2 writing: Research findings and pedagogical implications. TESL Canada Journal, 21(1), 39-63.

$\mathrm{Hu}$, J. (2005). Academic writing challenges of Chinese students in Canadian universities and implications for curricular change in China. Paper presented at the 3rd Annual Conference of the International Association of Teachers of English as a Foreign Language, China Branch, Tonghua, China. 
Hu, J. (2009). Discovering emerging research in a qualitative study of ESL academic writing. The Qualitative Report, 14(4), 629-644. Retrieved October 1, 2010, from http://www.nova.edu/ssss/QR/QR 144/hu.pdf

Huang, J., \& Klinger, D.A. (2006). Chinese graduate students at North American universities: Learning challenges and coping strategies. Canadian and International Education, 35(2), 48-61.

Lee, I. (2005). Error correction in the L2 writing classroom: What do students think? TESL Canada Journal, 22, $1-16$.

Leki, I. (1995). Coping strategies of ESL students in writing tasks across the curriculum. TESOL Quarterly, 29(2), 235-60.

Leki, I. (1998). Academic writing: Exploring processes and strategies $\left(2^{\text {nd }}\right.$ ed.). New York: Cambridge University Press.

Leki, I., \& Carson, J.G. (1994). Students' perceptions of EAP writing instruction and writing

needs

across the disciplines. TESOL Quarterly, 28(1), 81-100.

Liu, J. (2002). Negotiating silence in American classrooms: Three Chinese cases. Language and Intercultural Communication, 2(1), 37-54.

Myers, S. (1998). Questioning author(ity): ESL/EFL, science, and teaching about plagiarism. TESL-EJ, 3(2). Retrieved August 5, 2009, from http://tesl-ej.org/ej10/a2.html

Norton, B., and Starfield. S. (1997). Covert language assessment in academic writing. Language Testing, 14(3), 278-94.

Pennycook, A. (1996). Borrowing others' words: Text, ownership, memory and plagiarism. TESOL Quarterly, $30(2), 201-30$.

Picorari, D. (2003). Good and original: Plagiarism and patchwriting in academic second language writing. Journal of Second Language Writing, 12(4), 317-345.

Prior, P. (1991). Contextualizing writing and response in a graduate seminar. Written Communication, 8 , 267-310.

Prior, P. (1995). Redefining the task: An ethnographic examination of writing and response in graduate seminars. In D. Belcher \& G. Braine (Eds.), Academic writing in a second language: Essays on research and pedagogy (pp. 47-82). Norwood, NJ: Ablex.

Qian, J., \& Krugly-Smolska, E. (2008). Chinese graduate students' experiences with writing a literature review. TESL Canada Journal, 26(1), 68-86.

Shen, F. (1989). The classroom and the wider culture: Identity as a key to learning English composition. College Composition and Communication, 40(4), 459-66.

Shi, L. (2006). Cultural backgrounds and textual appropriation. Language Awareness, 15(4), 264-282. Retrieved August 15, 2009, from http://dx.doi.org/10.2167/la406.0

Silva, T. (1992). L1 vs. L2 writing: ESL graduate students' perceptions. TESL Canada Journal,

$10,27-47$

Stern, L. (2006). What every student should know about avoiding plagiarism. London: Longman.

"UBC Regulation on Plagiarism." Retrieved August 5, 2009, from http://www.vpacademic.ubc.ca/integrity/policies.htm

White, J. (Aug/Sept, 1998). A native speaker's perspective of EFL in China. TESOL Matters, 13.

Windle, S., Hamilton, B., Zeng, M., \& Yang, X. (2008). Negotiating the culture of the academic: Chinese graduate students in Canada. Canadian and International Education, 37(1), 71-90.

Dr. Jim Hu (jhu@tru.ca) is an Assistant Professor at Thompson Rivers University, where he teaches TESL certificate and English-for-academic-purposes (EAP) courses. His research interests include second languge academic writing, pedagogical grammar, teacher feedback, rhetoric and style, and second language writing problem analysis and treatment. 